Maurer School of Law: Indiana University

Digital Repository @ Maurer Law

1979

\title{
"We're Only Trying to Help": The Burden and Standard of Proof in Short-Term Civil Commitment
}

Lynne N. Henderson

Indiana University School of Law

Follow this and additional works at: https://www.repository.law.indiana.edu/facpub

Part of the Health Law and Policy Commons, and the Psychiatric and Mental Health Commons

\section{Recommended Citation}

Henderson, Lynne N., "'We're Only Trying to Help": The Burden and Standard of Proof in Short-Term Civil Commitment" (1979). Articles by Maurer Faculty. 1923.

https://www.repository.law.indiana.edu/facpub/1923

This Article is brought to you for free and open access by the Faculty Scholarship at Digital Repository @ Maurer Law. It has been accepted for inclusion in Articles by Maurer Faculty by an authorized administrator of Digital Repository @ Maurer Law. For more information, please contactrvaughan@indiana.edu. 


\section{NOTES}

\section{"We're Only Trying to Help": The Burden and Standard of Proof in Short-Term Civil Commitment*}

In 1972 Justice Blackmun noted that "[c]onsidering the number of persons affected, it is perhaps remarkable that the substantive constitutional limitations on [civil commitment] have not been more frequently litigated." Justice Blackmun may thereby have meant to imply that the procedural constitutional limitations on the state's power to commit a person to a mental hospital have received abundant legal attention. With respect to long-term or indefinite commitment, this view is accurate. Although a number of serious questions about substantive commitment standards remain unresolved, ${ }^{2}$ most of the procedural safeguards necessary to protect persons facing longterm commitment have been settled by courts ${ }^{3}$ and legislatures. ${ }^{4}$

* The author thanks George J. Alexander, Dean, University of Santa Clara School of Law, and Charles Halpern, Professor, Georgetown University Law Center, for their willingness to read earlier drafts of this note and for their helpful comments. Neither is responsible for the final outcome of this note, however.

1. Jackson v. Indiana, 406 U.S. 715, 737 (1972) (citations omitted) (indefinite commitment of person incompetent to stand trial violates due process and equal protection). Since Justice Blackmun's observation, the Supreme Court has decided only one case involving civil commitment. O'Connor v. Donaldson, 422 U.S. 563 (1975) (mere finding of "mental illness" does not permit a state to confine a nondangerous individual capable of surviving outside hospital). The Court will decide two other cases this term. J.L. v. Parham, 412 F. Supp. 112 (M.D. Ga. 1976), prob. juris. noted, 431 U.S. 936 (1977) (No. 75-1690) (standards for civil commitment of children); State v. Addington, 557 S.W.2d 511 (Tex. 1977), prob. juris. noled, 435 U.S. 967 (1978) (No. 77-5992) (standard of proof required of state in long-term civil commitment hearings).

2. See, e.g., Comment, Advances in Mental Health: A Case for the Right to Refiuse Treatment, 48 TEMP. L.Q. 354 (1975) (right to treatment and right to refuse treatment). See generally Developments in the Law-Civil Commitment of the Mentally Ill, 87 HARV. L. REv. 1190 (1974) [hereinafter cited as Developments-Civil Commitment].

3. Commitment proceedings, whether denominated "criminal" or "civil," are subject to both the equal protection and due process clauses. Specht v. Patterson, 386 U.S. 605 (1966) (sex offender commitment requires judicial hearing with right of counsel, confrontation, and 
Nevertheless, such procedural protection has not been provided persons facing short-term civil commitment. Short-term commitments, ranging from 2 weeks to 2 months in duration, ${ }^{5}$ are a relatively new form of involuntary hospitalization. ${ }^{6}$ Statutes authorizing such commitments may ensure some procedural protection, including some form of judicial review. ${ }^{7}$ Nevertheless, short-term commitment laws typically lack important elements of procedural due process, perhaps most notably a clear assignment of the burden of proof and a clear designation of the standard of proof. $^{8}$ Therefore, although in order to commit people for a long term the state must bear the burden of proof ${ }^{9}$ and generally meet the exacting standards of either proof beyond a reasonable doubt or clear and convincing

cross-examination of witnesses, and opportunity to be heard and present evidence). The courts have consistently extended specific procedural safeguards to different modes of commitment. See, e.g., Heryford v. Parker, 396 F.2d 393 (10th Cir. 1968) (right to counsel in juvenile commitment proceedings); Lessard v. Schmidt, 349 F. Supp. 1078 (E.D. Wis. 1972) (long-term commitment requires notice, right to counsel, probable cause hearing, and then full judicial hearing with privilege against self-incrimination, right to jury trial, exclusion of hearsay, and proof beyond reasonable doubt), vacated and remanded on other grounds, 414 U.S. 473 (1974), on remand, 379 F. Supp. 1376 (E.D. Wis. 1974), vacated and remanded on other grounds, 421 U.S. 957 (1975) reinstaled, 413 F. Supp. 1318 (1976).

4. See, e.g., ARIz. REv. STAT. ANN. $\$ \S 36-536$ to -540 (1974) (notice, counsel, hearing with standard of proof of clear and convincing evidence); CAL. WELF. \& INST. CODE $§ 5350$ (West Supp. 1978) (notice, counsel, hearing, and jury trial); TEx. REv. Crv. STAT. ANN. art. 5547-40 to -57 (Vernon 1958 \& Supp. 1978) (notice, counsel, jury trial, and right to appeal).

5. Compare GAL. WELF. \& INST. CODE $§ 5250$ (West 1972) (14 days) with N.Y. MENTAL Hyg. LAW § 9.33(a) (McKinney 1978) (60 days). The Mental Health Law Project's model civil commitment statute follows the California rule of 14 days. Legal Issues in State Mental Health Care: Proposals for Change-Civil Commitment, Suggested Statute on Civil Commilment, 2 MENTAL Disability L. ReP. 73, 127 (1977) [hereinafter cited as MHLP Proposal].

For the purposes of this note, "short-term" commitment means nonemergency commitments that automatically terminate at some point no later than 2 months after they begin, but which may then be extended into longer-term commitment by judicial process. Such commitments must be distinguished from such brief emergency procedures as California's 72hour "hold." See notes 22-23 infra and accompanying text.

6. A 1973 survey showed that although the states authorized "emergency" hospitalizations of varying length, the civil commitment laws of 21 states made no provision for shortterm nonemergency commitments, and 3 states provided only for indefinite commitments. $B$. Ennis \& L. Siegel, The Rights of Mental Patients 93-282 app. A (1973).

7. See, e.g., CAL. Welf. \& INST. Code §§ 5250-5253, 5275, 5276 (West 1972 \& Supp. 1978) (notice, counsel, habeas corpus review); WASH. REv. CODE ANN. $\$ 71.05 .310$ (Supp. 1978) (notice, counsel, probable cause hearing).

8. A few courts have required a prompt hearing at which the state must show probable cause to justify short-term nonemergency detention of a person. In re Barnard, 455 F.2d 1370 (D.C. Cir. 1971); Lessard v. Schmidt, 349 F. Supp. 1078 (E.D. Wis. 1972), vacated and remanded on other grounds, 414 U.S. 473 (1974), on remand, 379 F. Supp. 1376 (E.D. Wis. 1974), vacaled and remanded on other grounds, 421 U.S. 957 (1975), reinstated, 413 F. Supp. 1318 (1976).

9. E.g., Lynch v. Overholser, 369 U.S. 705, 709, 711 (1962) (dictum); People v. Redmond, 16 Cal. App. 3d 931, 94 Cal. Rptr. 543 (2d Dist. 1971). 
evidence, ${ }^{10}$ the state may commit a person to short-term involuntary hospitalization with little judicial scrutiny.

California's Lanterman-Petris-Short Act (LPS Act) ${ }^{11}$ provides a useful example of the problems of the burden and standard of proof appropriate in short-term civil commitment proceedings, because it has served as a model for civil commitment statutes in other states ${ }^{12}$ and closely parallels the Mental Health Law Project's model commitment law. ${ }^{13}$ The LPS Act authorizes a 14-day "certification" period in which persons may be involuntarily hospitalized, ${ }^{14}$ and grants such persons the right to notice, counsel, and judicial review by habeas corpus. ${ }^{15}$ These provisions may appear to give individuals ample protection from erroneous commitment. But in designating the certification hearing a habeas corpus proceeding, the legislature may have mistakenly placed the burden of proof on the individual, and the statute is completely silent on the question of standard of proof. ${ }^{16}$ As a result of these flaws in the statute, judges frequently decide certification cases on an ad hoc basis without uniform standards of evidence. ${ }^{17}$

10. See, e.g., In re Ballay, 482 F.2d 648 (D.C. Cir. 1973) (reasonable doubt); In re Stephenson, 67 Ill. 2d 544, 367 N.E.2d 1273 (1977) (clear and convincing evidence). The Supreme Court, however, will be deciding this term whether a preponderance of the evidence standard meets minimal constitutional standards. State v. Addington, 557 S.W.2d 511 (Tex. 1977), prob. juris. noted, 435 U.S. 967 (1978) (No. 77-5992).

11. Cal. Welf. \& INST. CODE $§ \S 5000$ to 5404.1 (West 1972 \& Supp. 1978).

12. See Developments-Civil Commilment, supra note 2, at 1205-06 (noting statutes in Massachusetts, North Carolina, and Washington).

13. See MHLP Proposal, supra note 5, at 131-59. The availability of empirical studies on the effect of the LPS Act also make it a useful basis for analysis. See ENKI ReSEARCH INSTItute, A Study Of Galifornia's New Mental Health LaW (1972); Warren, Involuntary Commitment for Mental Disorder: The Application of Califomia's Lanterman-Petris-Short Act, 11 LAW \& Soc'y REv. 629 (1977). For other studies of the Act, see Tieger \& Kresser, Civil Commitment in Califormia: A Defense Perspective on the Operation of the Lanterman-Petris-Short Act, 28 HAstings L.J. 1407 (1977); Comment, Civil Commilment of the Mentally Ill in Califomia: The LantermanPetris-Short Act, 7 Loy. L.A.L. REv. 93 (1974); Comment, Civil Commitment of the Mentally Ill in Califomia: 1969 Style, 10 Santa Clara Law. 74 (1969).

14. CAL. Welf. \& INST. CODE $§ 5250$ (West 1972).

15. Id. §5252.1.

16. See note 93 infra and accompanying text.

17. Judges often do not even state the basis of their decisions. At a certification hearing in 1977, for example, the petition for release was denied. The certified individual asked the judge why his writ was denied, and the judge replied, "[The public defender representing the person] will go into it more completely with you." First Hearing of August 26, 1977, Santa Clara County Superior Court, Rhodes, J., presiding. In another hearing held the same day, the judge simply stated that the evidence was "clear" that the individual was gravely disabled. Second Hearing of August 26, 1977, Santa Clara County Superior Court, Rhodes, J., presiding.

One observer found that judges frequently based their rulings on grounds not included 
Because short-term commitments are significant deprivations of liberty, they fall within the coverage of due process. This note, focusing on California's 14-day certification as the basis for analysis, examines whether due process requires any particular assignment of the burden of proof and designation of the standard of proof in shortterm commitments. Part I outlines the structure of civil commitment under the LPS Act and describes the role of 14-day certifications. Part II argues that despite the labeling of the certification hearing as a habeas corpus proceeding, a balance of the individual and state interests at issue in certifications requires that the burden of proof be placed on the state. Part III considers the range of standards of proof that could be applied to the state's burden, and proposes that the standard of clear and convincing evidence best protects both individual and state interests, while giving judges the flexibility they need in difficult certification cases. The note concludes that California and other states should amend their civil commitment statutes to incorporate these procedural protections. ${ }^{18}$

\section{The Background of the Problem: Short-Term COMMITMENTS UNDER THE LPS ACT}

The California Legislature passed the LPS Act in 1967 in response to increasing criticism of the state's civil commitment system. ${ }^{19}$ That system had provided only two forms of commitment: a 72-hour "hold" for emergencies and an indefinite commitment. ${ }^{20}$

in the statute. Warren, supra note 13, at 633-39. Another observer found that judges based their decisions on their own subjective feelings about individuals rather than on legal standards. M. Fiala, An Examination of the Expert's Role in Civil Commitment Hearings 56-57 (1976) (unpublished manuscript on file with the Stanford Law Review).

18. A legislative solution is preferable, since litigation of short-term commitment issues is very difficult: The gap in time between denial of release at a certification hearing and the perfection of an appeal will cause most appellate courts to dimiss a claim as moot. Interview with Larry Smith, California State Public Defender's Office, in Sacramento (June 21, 1977); Interview with Steve Stevens, Santa Clara County Public Defender's Office, in San Jose (July 18, 1977).

19. Before the passage of the LPS Act, over a thousand people a month were committed to the state's hospitals, and commitment hearings were perfunctory affairs that often took less than 5 minutes to complete. For a discussion of the problems in the California civil commitment system prior to the LPS Act, see Subcomm. on Mental Health Services of the Assembly Interim Comm. on Ways \& Means, The Dilemma of Mental CommitMENTS IN CALIFornia: A BaCkground DOCumEnt 6-83 (1967) [hereinafter cited as DIlemma of Mental Commitments]; Note, The Need for Reform in the Califoria Civil Commitment Procedure, 19 STAN. L. REV. 992 (1967).

20. See ENKI RESEARCH INSTTTUTE, supra note 13, at 130; Note, supra note 19, at 992-95. People also could be indefinitely committed as a result of detention orders growing out of "mental illness petitions" or transfers from jails to hospitals. Dilemma of Mental COMMITMENTS, supra note 19 , at 21-27. 
The primary concern of the drafters of the LPS Act was the frequent abuse of patients' rights caused by the absence of any nonemergency alternatives to indefinite commitment. ${ }^{21}$

The LPS Act created a 3-tier structure: (1) an emergency 72-hour hold for treatment and evaluation; ${ }^{22}$ (2) a 14-day certification for "intensive treatment"; ${ }^{23}$ (3) a long-term commitment, in the form of either a 90-day post-certification for dangerous patients ${ }^{24}$ or a 1-year conservatorship for "gravely disabled" patients. ${ }^{25}$

\section{A. The Role of 14-Day Certifications}

If a person placed on a 72-hour hold appears in need of further treatment, the certification process enables the state to provide that treatment without subjecting the person to long-term commitment. ${ }^{26}$ Although the state can only begin a post-certification or conservatorship commitment under a court order and after the patient has been given the opportunity for a full jury trial, ${ }^{27}$ a 14-day certification is not reviewed by a court unless the individual requests a habeas corpus hearing after confinement under the certification has begun. ${ }^{28}$ The certification process therefore makes it legally possible for the state to hospitalize persons for up to 20 days without judicial scrutiny. ${ }^{29}$ Moreover, the absence of automatic judicial review allows the state to use a series of 14-day certifications and releases to achieve de

21. E. Bardach, The Skill Factor in Politics 145-48 (1972). The Act was largely a product of the efforts of the three men whose names appear in the title: Frank Lanterman, Nicholas Petris, and Alan Short. Id.

22. CAL. Welf. \& Inst. CoDe $\S 5150$ (West Supp. 1978).

23. Id. $\S 5250$ (West 1972). If an individual is still dangerous to himself at the end of the certification period, he may be recertified for an additional 14 days. Id. $\S 5260$. Individuals who are still gravely disabled at the end of the certification period may be placed on a 30 day "temporary conservatorship" for further observation. Id. $§ \S 5352,5352.1,5353$ (West Supp. 1978).

24. Id. $\S 5300$ (West 1972).

25. Id. $\S \S 5350,5361$ (West Supp. 1978).

26. The legislature that passed the LPS Act felt, and prevailing medical opinion indicated, that the majority of people committed require no more than 2 weeks of hospitalization to recover sufficiently to leave the hospital. Dilemma of MENTal Commitments, supra note 19, at 139-42. A study of the effect of LPS found that the prognosis for patients at discharge under the LPS Act's mandatory release program was as good as the prognosis for patients who were discharged before the Act, when physicians had an unlimited time to treat patients and release was determined solely on a medical basis. ENKI RESEARCH INSTITUTE, supra note 13 , at 143.

27. CAl. Welf. \& INST. Code $\S \S 5302,5350$ (d) (West $1972 \&$ Supp. 1978).

28. Id. $\S 5252.1$ (West 1972).

29. The 72-hour period does not include weekends or holidays, id. $§ 5253$ (West Supp. 1978), so a person hospitalized on a 72-hour hold on the Wednesday before a 3-day weekend can be held for 6 days before being placed on a 14-day certification. 
facto long-term commitment without court review. ${ }^{30}$ The hospital staff may also use even a single 14-day certification to establish a psychiatric record to support a petition for imposing post-certification commitment or conservatorship on the patient.

\section{B. Standards for 14-Day Certifications}

\section{Substantive standards.}

The hospital staff may certify a patient on grounds that the patient is "dangerous" or "gravely disabled" as a result of a "mental disorder."31 "Dangerousness" includes danger to self or others: Persons are dangerous to themselves if they have attempted suicide prior to or during the 72-hour hold and if they present an "imminent threat" of making another attempt. ${ }^{32}$ Persons are dangerous to others if they "threatened, attempted, or inflicted physical harm" on another person before or during the 72-hour period and present an "imminent threat of substantial physical harm" to others. ${ }^{33}$

The majority of certifications fall under the "gravely disabled" standard. ${ }^{34}$ A person is "gravely disabled" if unable to provide the basic needs of food, clothing, and shelter..$^{35}$ A legislative report indicates that the standard was intended to include only those persons "incapable of carrying on transactions necessary to survival,"36 but

30. Evidence of this "revolving door" phenomenon appears in unpublished statistics from the Santa Clara County Public Defender's Office (on file with Slanford Law Review).

31. "Mental disorder" is defined as any mental disorder described in the American Psychiatric Association's Diagnostic and Statistical Manual II. CAL. ADMIN. CODE tit. 9, §813 (1977); see Comm. on Nomenclature \& Statistics of the American Psychiatric Ass'n, DSM-II, Diagnostic and Statistical Manual of Mental Disorders (1968). This definition is quite elastic, since $D S M-I I$ includes mental disorders ranging from mild character disorders to severe psychoses. DSM-II even has a category for "social maladjustments without manifest psychiatric disorder" which is defined as a category "for recording the conditions of individuals who are psychialrically normal but who nevertheless have severe enough problems to warrant examination by a psychiatrist." Id., quoted in F. MilleR, R. Dawson, G. Dix \& R. Parnas, The Mental Health Process 42 (2d ed. 1976) (emphasis added). Presumably, this "disorder" would be sufficient to provide the "mental disorder" necessary for certification. One study of certifications found that the mental disorders attributed to individuals at certification hearings did vary from paranoid schizophrenia to anhedonia (inability to enjoy life). Warren, supra note 13, at 632.

32. Cal. WelF. \& INST. CODE § 5260(a) (West 1972).

33. Id. $\S 5300$.

34. Tieger \& Kresser, supra note 13, at 1417; Warren, supra note 13, at 645.

35. CaL. Welf. \& INST. CODE § 5008(h) (West Supp. 1978).

36. Dilemma of Mental Commitments, supra note 19 , at 133 (emphasis omitted). A recent challenge to the standard was rejected by the California Court of Appeal. Conservatorship of Chambers, 71 Cal. App. 3d 277, 139 Cal. Rptr. 357 (1st Dist. 1977). The court noted that, "The term 'gravely disabled' is sufficiently precise to exclude unusual or nonconformist lifestyles. It connotes an inability or refusal on the part of [the individual] to care for basic personal needs of food, clothing and shelter." Id. at 284, 139 Cal. Rptr. at 362 . Signifi- 
this standard is not strictly applied. ${ }^{37}$

\section{Procedures.}

At the end of the 72-hour hold, the professional staff ${ }^{38}$ of the hospital may certify a person for an additional 14 days of hospitalization if it determines that the person suffers from a mental disorder resulting in dangerousness or grave disability. ${ }^{39}$ The staff must tell the person he has been certified and inform him of his right to counsel, including court-appointed counsel for indigents, and to judicial review by habeas corpus. ${ }^{40}$ The hospital must notify the superior court if the individual requests a hearing, ${ }^{41}$ and an evidentiary hearing must be held within 2 court days of the request. ${ }^{42}$ The court must order the individual released from the hospital if it finds that the individual is not mentally ill, dangerous, or gravely disabled. ${ }^{43}$

The statute provides several important safeguards against errone-

cantly, the court used the phrase "food, clothing and shelter" rather than the statutory language of "food, clothing, or shelter."

37. One study has found that courts are "generally supportive of the hospital's contention that the patient 'needs treatment" "regardless of whether the individual actually falls within the statutory criteria. ENKI RESEARCH INSTITUTE, supra note 13, at 184. Another study found that the application of the "gravely disabled" standard has little relation to the statutory definition. Prior hospitalizations, refusal to take medication, denial of illness, lack of cooperation in the hospital, and rejection by the family were all used as evidence of grave disability, although none of these factors indicates an inability to provide for food, clothing, or shelter as required by the statute. Warren, supra note 13, at 633-38.

A judge approved the certification of a legal secretary in her mid-twenties on the basis of testimony that she had been "conned" out of some money; the judge determined that the woman had "poor judgment" about money and was therefore unable to provide for herself, even though she was employed, kept her own apartment, was neatly dressed, and was not suffering from malnutrition. Hearing of July 19, 1977, Santa Clara County Superior Court, Longinotti, J., presiding.

38. "Professional staff" is not defined, but obviously includes psychiatrists, physicians, and psychologists, and may include nurses and psychiatric social workers. Nevertheless, the statute expresses a preference for certification by a psychiatrist. CAL. WELF. \& INST. CODE $\S 5251$ (West 1972).

39. Id. $\$ 5250$.

40. Id. $\S 5252.1$. The staff must also explain the meaning of review by habeas corpus to the certified individual. Id.

41. The person may request a hearing immediately upon certification or at any time during the certification period. Intentional failure to notify the superior court of the county in which the person is certified is a misdemeanor. Id. $\S 5275$. A request for release is suffcient to require a hearing. $I d$. The individual has a right to a public hearing, and in many counties the hearings are regularly held at the superior courthouse. The hearings are routinely transcribed by a court reporter. A constitutional argument that the hearing should be mandatory was rejected in Thorn v. Superior Court, 1 Cal. 3d 666, 464 P.2d 56, 83 Cal. Rptr. 600 (1970).

42. Cal. Welf. \& INST. Code $\S 5276$ (West 1972).

43. Id. Furthermore, if the hospital has failed to inform the person of his rights, notify 
ous certification for individuals, including notice, counsel, and a hearing. But it also omits two essential safeguards: The statute appears to place the burden of proof on the individual to demonstrate that the certification is unwarranted, and it is completely silent on the standard of proof required to meet the burden. The next part discusses whether the state may constitutionally require the individual to bear the burden of proof in 14-day certification hearings.

\section{The Burden of Proof in Short-Term Commitments}

The assignment of the burden of proof ${ }^{44}$ can determine the result of a certification hearing. If the state bears the burden, it will have to show that the individual is mentally ill and dangerous or gravely disabled through the testimony of the certifying psychiatrist or other hospital personnel. If the individual bears the burden, on the other hand, he will have the difficult task of disproving the state's allegations, and, as a practical matter, will probably have to do so without independent experts or other favorable witnesses. ${ }^{45}$

\section{A. The Effect of the Provision for Habeas Corpus Relief}

The LPS Act's silence on the question of burden of proof may have its source in the political background of the statute. Fourteenday certifications developed as a compromise between civil libertarian interests arguing that no one should be hospitalized beyond the 72-hour emergency period without a mandatory court hearing, and medical interests arguing for minimum legal interference in the treatment of mental disorders. ${ }^{46}$ The legislature recognized the civil libertarian interests by providing for notice, right to counsel, and habeas review upon request, and recognized the medical interests by allowing for legal commitment for up to 20 days without mandatory

him of the certification, or is an unaccredited hospital, the judge must order the person released. Id.

44. "Burden of proof" actually has two separate meanings. The party with the burden of proof may bear the burden of going forward with the production of evidence or the burden of persuading the factfinder. For the purposes of this note, "burden of proof" includes both these elements. See McNaughton, Burden of Production of Evidence: A Function of a Burden of Persuasion, 68 HaRv. L. Rev. 1382 (1955).

45. The statute does not provide for independent experts, and the expense and difficulty of retaining a psychiatrist to testify in his behalf may be prohibitive for the individual. Moreover, an impartial observer is not likely to be present at the time the person is notified of the certification to observe if the staff properly follows certification procedure. Petitioners are therefore likely to be at a great disadvantage at their hearings, relying chiefly on their own testimony and demeanor. Tieger \& Kresser, supra note 13, at 1417; see note 90 infra and accompanying text.

46. ENKI RESEARCH INSTITUTE, supra note 13, at 15. 
court review. ${ }^{47}$ The compromise was apparently so delicate that further pressure from either side might have caused the collapse of the entire LPS Act. ${ }^{48}$ The legislature's silence on the burden of proof may therefore have been a deliberate attempt to avoid a troublesome issue.

The LPS Act's failure to assign the burden of proof in certification hearings, whether deliberate or inadvertent, would seem to invite the courts to make that assignment themselves upon basic due process principles. ${ }^{49}$ But one argument stands in the way of the due process approach: The legislature made the certification hearing a habeas corpus proceeding, and the history of the writ finds the burden of proof traditionally placed on the petitioner. ${ }^{50}$

One plausible explanation for the legislature's decision to provide for review by habeas, a reason rooted in an ancient use of the writ, ${ }^{51}$ is to ensure that certified patients will be allowed to come to court to attend their hearings. ${ }^{52}$ But that basis for the writ is irrelevant to the traditional view that habeas places the burden on the petitioner. The assignment of burden of proof in habeas proceedings stems from the most frequent modern use of the writ-to allow review of courtimposed custody. When used for this purpose, the habeas proceeding demands placing the burden on the petitioner, to ensure the presumption that the original court-approved confinement was proper. ${ }^{53}$ That concept of habeas, however, is obviously inapplicable to certification hearings, since the patient's original confinement through the

47. See note 29 supra and accompanying text.

48. A legislative aide working for one of the sponsors stated, "The ship we are trying to float can sink very easily with too much weight on one side or another." E. BARDACH, supra note 21 , at 118 .

49. Two authors of the Act stated that the Act was intended to provide "full due process protection" for individuals. F. LANTERMan \& N. PETris, The MENTal Health ACT of 1967, ASSEMBLY BILL 1220, at 12 (1967).

50. See Johnson v. Zerbst, 304 U.S. 458, 468-69 (1938).

51. See Developments in the Law-Federal Habeas Corpus, 83 Harv. L. REv. 1038, 1042 (1970) (habeas emerged in England as procedure to ensure court attendance of both parties to an action) [hereinafter cited as Developments-Habeas].

52. Prior to the LPS Act, a court could authorize the sheriff to take a person into custody and detain him for an indefinite period as a result of an ex parte proceeding. Project, Civil Commitment of the Mentally Ill, 14 U.C.L.A. L. REv. 822, 845-51 (1967). During the negotiations leading to the Act, medical interests argued that it would be unduly "traumatic" to patients if they attended the hearings. See, e.g., ENKI RESEARCH INSTITUTE, supra note 13 , at 15. Even without the specific provision of the LPS Act, a patient would have the common law right to petition through habeas corpus to challenge the legality of his or her confinement. See, e.g., In re Franklin, 7 Cal. 3d 126, 496 P.2d 465, 101 Cal. Rptr. 553 (1972).

53. See Developments-Habeas, supra note 51, at 1044-45 (statutory habeas corpus developed as a means to challenge executive detention). 
72-hour hold and certification by the hospital staff will never have been tested by a court. ${ }^{54}$ The argument that the individual must bear the burden of proof in a certification hearing because the hearing is a habeas proceeding is therefore a weak one $\mathrm{e}^{55}$ and conventional due process analysis must be invoked to fill the legislative gap.

Due process analysis begins with a measure of the individual and state interests at odds in a given proceeding. When the individual interests at stake fall within the "life, liberty or property" language of the 14th amendment, the courts must balance the individual interests against those of the state to determine what procedures due process requires. ${ }^{56}$ When the individual interest at stake in a burden of proof issue is personal liberty, the courts have regarded the potential loss of that liberty as "grievous," and have generally determined that the balance tips in favor of placing the burden on the state. ${ }^{58}$ Thus, any interest-balancing in a new context involving personal liberty begins with a heavy presumption in favor of placing the burden on the state. The next two sections identify the individual and state interests to determine whether the state can overcome that presumption in short-term commitment proceedings.

54. In this sense, the certification is identical to an initial commitment hearing, at which the patient has the right to a full jury trial, see note 27 supra and accompanying text, and for which habeas would therefore be an inadequate remedy. See, e.g., Baxstrom v. Herold, 383 U.S. 107 (1966) (holding convicted criminal in mental hospital beyond original criminal sentence without new jury trial violates equal protection, because civil commitment requires jury trial; habeas inadequate by implication); United States ex rel. Schuster v. Herold, 410 F.2d 1071 (2d Cir. 1969) (habeas provision placing burden of proof on petitioner inadequate to protect convict being transferred to mental hospital, since burden normally on state in commitment hearings). A habeas procedure is nevertheless adequate, and the burden properly placed on the individual, when a patient seeks release from a legally established long-term commitment. See Overholser v. O’Beirne, 302 F.2d 852 (D.C. Cir. 1962); In re Franklin, 7 Cal. 3d 126, 496 P.2d 465, 101 Cal. Rptr. 553 (1972).

55. Cf. Matthews v. Hardy, 420 F.2d 607, 612 n.14 (D.C. Cir. 1969) (habeas proceeding to review initial commitment of convicted criminals or dangerous patients to maximumsecurity mental hospital violates equal protection); Dixon v. Attorney General, 325 F. Supp. 966 (M.D. Pa. 1971) (same on both equal protection and due process grounds).

56. Board of Regents v. Roth, 408 U.S. 564, 571 (1972); see Note, "Liberly," "Property," and Procedural Due Process, 56 OR. L. REv. 137, 140 (1977).

57. Morrissey v. Brewer, 408 U.S. 471,482 (1972).

58. See, e.g., id. at 488 (parole revocation proceeding); In re Winship, 397 U.S. 358, 364, 368 (1970) (criminal and juvenile delinquency proceedings); Lynch v. Overholser, 369 U.S. 705, 709, 711 (1962) (civil commitment proceedings) (dictum); People v. Redmond, 16 Cal. App. 3d 931, 94 Cal. Rptr. 543 (2d Dist. 1971) (civil commitment); ff. Gerstein v. Pugh, 420 U.S. 103 (1975) (probable cause hearing after arrest). 


\section{B. The Individual Interests at Stake in Certification Hearings}

\section{Liberty.}

Even a short-term civil commitment impinges on an individual's most elemental physical liberty. ${ }^{59}$ Certified patients cannot leave the hospital without official permission, and may even find themselves in locked wards. ${ }^{60}$ The constraint on liberty may continue even after the certification period ends, since the patient may be required to report to the hospital periodically or continue taking medication, ${ }^{61}$ and $a$ failure to do either may result in additional confinement. ${ }^{62}$ Moreover, individuals released after certification often fall under close surveillance by the police. ${ }^{63}$

\section{Stigma.}

Although stigma has not been identified as a separate due process interest ${ }^{64}$ it assumes constitutional importance when combined with loss of physical liberty. Civil commitment imposes demonstrable social stigma on patients; ${ }^{65}$ people labeled as mentally ill suffer more

59. "Although 7 days may not appear to some to be a very long time, experience has indicated that any kind of forcible detention of a person in an alien environment may seriously affect him . . ." Hearings Before the Senate Subcomm. on Constitutional Rights, 91st Cong., 1st \& 2d Sess. 210 (1969-1970) (statement of Arthur Cohen, ACLU attorney); see E. GOFFMAN, ASYLUMS 146-49 (1961) (initial days of hospitalization are often most difficult for patient); Chambers, Altematives to Civil Commitment of the Mentally Ill: Practical Guides and Constitutional Imperatives, $70 \mathrm{MICH}$. L. Rev. 1 108, 1130 (1972) (many patients adjust to hospital by means of withdrawal and other defenses; hospitalization itself can cause long-lasting mental illness).

60. See Brief for Appellant at 15-18, Addington v. Texas, 435 U.S. 967 (1978) (No. 77 5992) (noting probable jurisdiction). The locked ward serves not only to control the violent patient, but also to coerce even the nonviolent patient to behave in a way deemed appropriate by the hospital staff. E. GofFMAN, supra note 59, at 85-86; Ferleger, Loosening the Chains: In-Hospital Civil Liberties of Mental Patients, 13 SANTA Clara Law. 447 (1973). For a patient's own account of the use of the locked ward to control behavior, see K. DONALDSON, INSANITY INSIDE OUT (1976).

61. American Bar foundation, The Mentally Disabled and the Law 136-38 (rev. ed. S. Brakel \& R. Rock eds. 1971).

62. Warren, supra note 13 , at $634-35$.

63. See Steadman \& Keveles, The Communily Adjustment and Criminal Activities of the Baxstrom Patients 1966-1970, 129 AM. J. PsYCH. 304, 309 (1972) (innocent behavior such as sleeping on park benches, ignored in other cases, resulted in arrests of ex-mental patients previously committed as dangerous to others).

64. Paul v. Davis, 424 U.S. 693 (1976) (reputation not liberty or property interest). But see Note, Reputation, Stigma and Section 1983: The Lessons of Paul v. Davis, 30 STAN. L. Rev. 191 (1977).

65. F. Miller, R. Dawson, G. Dix \& R. Parnas, supra note 31, at 240; Sarbin \& Mancuso, Failure of a Moral Enterprise: Attiludes of the Public Toward Mental Illness, $35 \mathrm{~J}$. CONsulting \& Clinical Psych. 159 (1970). Professor Rosenhan's well-known study demon- 
employment discrimination and general social rejection than released convicted criminals. ${ }^{66}$ The extent of stigma resulting from 14day certifications in particular has not been fully studied, ${ }^{67}$ but because stigma attaches even to voluntary patients consulting private therapists, the certified patient is not likely to escape it. ${ }^{68}$

\section{Unwanted treatment.}

Although the state rarely requires physically ill people to seek medical attention or accept a given treatment, ${ }^{69}$ it frequently denies a similar freedom of choice to individuals suffering from mental disorders. $^{70}$ California law does give individuals an absolute right to

strates that diagnostic labels become self-fulfilling prophecies for later interpretations of behavior, even if that behavior is perfectly "normal." Rosenhan, On Being Sane in Insane Places, 13 SANTA Clara LAW. 379, 396 (1973). Stereotypes of how mentally ill persons behave determine society's perception of, and interaction with, a person labeled as mentally ill. T. Scheff, Being Mentally Ill 64-80 (1966). Moreover, the individual may engage in a kind of self-labeling process, thereby losing the self-esteem necessary to mental health or learning to behave as mentally ill people are "supposed to" behave. Id. at 84-86. The "learned helplessness" resulting from self-labeling may itself cause mental illness, especially depression. M. Seligman, Helplessness (1975).

66. See Harasymiw, A Longitudinal Study of Disability Group Acceptance, 37 ReHabILITATiOn Literature 98 (1976); Tringo, The Hierarchy of Preference Toward Disability Groups, $4 \mathrm{~J}$. SPECIAL EDUC. 295 (1970). "Knowledge of previous psychiatric treatment and/or the possession of a psychiatric label is . . . used prejudiciously to exclude individuals, as if society's institutions were attempting to protect themselves against what is felt to be a threat." American Psychiatric Association, Position Statement on Discrimination Against Persons with Previous Psychialric Trealment, 135 AM. J. Psych. 643, 643 (1978).

67. A study done after the LPS Act had been in effect for 2 years found that individuals did not perceive employment discrimination as a result of their certifications, but the study did not determine whether the fact of certification actually arose between the subjects and their employers. ENKI RESEARCH INSTITUTE, supra note 13, at 149.

68. Bord, Rejection of the Mentally Ill: Continuities and Further Developments, 18 Soc. PROB. 496 (1971). People might assume that a person absent from home or work for 17-20 days may simply be on vacation or physically ill, or may at least be more tolerant of someone with a short-term "problem" than one who has been so "sick" as to require long-term hospitalization. Id. But the cause of such an absence is likely to become known, and the individual will be identified not only as mentally ill, but also as "dangerous" or "gravely disabled." See, e.g., Ennis \& Litwack, Psychiatry and the Presumption of Expertise: Flipping Coins in the Courtroom, 62 Calif. L. Rev. 693, 716 (1974).

69. Physically ill people generally are protected from involuntary treatment by common law tort doctrine, absent an emergency. McCoid, A Reappraisal of Liability for Unauthorized Medical Treatment, 41 MINN. L. REV. 381 (1957).

70. Involuntarily committed patients usually cannot refuse prescribed treatment, Developments-Civil Commitment, supra note 2, at 1194 \& n.2, on the presumption that their illness prevents them from making rational choices to consent, Livermore, Malmquist \& Meehl, On the Justifications for Civil Commilment, 117 U. PA. L. REv. 75, 88 (1968). Nevertheless, many mental disorders affect only a small portion of an individual's thinking and behavior, and leave him capable of making rational choices about treatment. A. STONE, MENTAL HEALTH LAW: A SYSTEM IN TRANSITION 47 (1976). Chief Justice Burger urged consideration of a right to refuse treatment in O'Connor v. Donaldson, 422 U.S. 563, 580-83 (1975) (Burger, 
refuse the most drastic forms of treatment-psychosurgery and electroconvulsive therapy ${ }^{71}$ — but it does not give mental patients a right to refuse medication or other forms of treatment. Certified patients refusing medication may receive it by force or other forms of coercion. $^{72}$

\section{The State Interests Served by Certification}

\section{Police power: the dangerousness standard.}

State confinement of individuals who are mentally ill and dangerous to the safety of society or themselves has long been a legitimate function of the state's police power to protect the public health, welfare, and safety. ${ }^{73}$

Although few mentally ill people are dangerous, ${ }^{74}$ many of the most notorious murderers in recent memory were mentally ill at the time of their crimes. ${ }^{75}$ The purpose of the police power is to isolate such people before they wreak havoc on society. And though few mentally ill persons are suicidal, failure to intervene when a mentally

C.J., concurring), and lower courts have fashioned such a right on a number of grounds. E.g., Scott v. Plante, 532 F.2d 939 (3d Cir. 1976) (first amendment protection of individual's thoughts); Knecht v. Gillman, 488 F.2d 1136 (8th Cir. 1973) (eighth amendment prohibition of cruel and unusual punishment); Winters v. Miller, 446 F.2d 65 (2d Cir.), cert. denied, 404 U.S. 985 (1971) (freedom of religion); Bell v. Wayne County Gen. Hosp., 384 F. Supp. 1085 (E.D. Mich. 1974) (right to privacy); see Plotkin, Limiting the Therapeutic Orgy: Mental Patient's Right to Refuse Treatment, 72 Nw. L. REv. 461, 490-97 (1977).

71. Cal. Welf. \& Inst. Code $\S 5325(f)$ to (g) (West Supp. 1978).

72. See, e.g., D. Chandler \& A. Sallychild, The Use and Misuse of Psychiatric Drugs in California's Mental Health Programs 37-38, $71-75$ \& Tables 23-28 (1977). Psychoactive medications can have unpleasant and sometimes harmful effects on patients. These effects range from dizziness, drowsiness, slurred speech, dryness of the mouth, and muscle spasms to heart failure and tardive dyskinesia, a frequently irreversible condition in which the person loses control of facial and limb movements. Id. at 15-18. See also Editorial: Neurological Syndromes Associated with Antipsychotic Drug Use, A Special Report, 28 ARCHIVES GEN. Psych. 463 (1973).

73. Some argue that the police power is the only justification for civil commitment, e.g., A. STONE, supra note 70 , at $25-26$, but a parens patriae power has been invoked to justify commitment of at least those dangerous to self, see, e.g., In re Ballay, 482 F.2d 648, 658 (D.C. Cir. 1973). But see Developments-Civil Commitment, supra note 2, at 1225 (prevention of suicide part of police power, since suicide may affect family and others).

74. D. LUNDE, MURDER AND MADNESS 35 (1975) (negative correlation between murder and mental illness); Steadman \& Keveles, supra note 63, at 307 (fewer than 3\% of persons committed as criminally dangerous and ordered released later confined for dangerous behavior).

75. For example, the crimes of Herbert Mullin, "a classic example of a mentally ill mass murderer," and John Linley Frazier, another mentally ill mass murderer, might have been prevented had efforts to hospitalize them not failed. D. LUNDE, supra note 74, at 63-64, 49-52. 
ill person is suicidal is often disastrous. ${ }^{76}$

\section{Parens patriae: the gravely disabled standard.}

Parens patriae, literally "parent of the country,"77 originally developed as a justification for a king to take control of persons and property in order to prevent dissipation of valuable estates by incompetent tenants. ${ }^{78}$ Parens patriae later developed in America as a justification for state-sanctioned civil commitments, ${ }^{79}$ and today serves as the rationale for realizing the state's humanitarian interests in caring for those who cannot care for themselves.

The Supreme Court recently limited the reach of the parens patriae power in $O^{\prime} C o n n o r v$. Donaldson. ${ }^{80}$ The Court held that a state cannot constitutionally confine "without more" nondangerous persons capable of surviving safely by themselves or with the help of others, ${ }^{81}$ it emphasized in dictum that committing a person simply because he is mentally ill or because the state wishes to assure the person a better standard of living is unconstitutional. ${ }^{82}$

\section{Reconciling the Interests}

Threatened with a loss of liberty for up to 20 days, social stigma, and forced treatment, individuals have considerable reason to insist that the state bear the burden of proving the need for certification.

76. Prompt intervention may prevent successful suicides or future suicide attempts. See Note, Civil Commitment in Califormia, 1969 Style, supra note 13, at 93.

77. Black's LAW DictionaRy 1269 (4th ed. 1968).

78. By the time of the American Revolution, the king of England had absolute authority to act as guardian of all "idiots, infants and lunatics" to protect their personal welfare and their property. Hawaii v. Standard Oil Co., 405 U.S. 251, 257 (1972) (quoting 3 W. BlAcKSTONE, COMMENTARIES *47).

79. D. Rothman, The Discovery of the Asylum (1971).

80. 422 U.S. 563 (1975).

81. Id. at 575-76. The Court did not directly address the issue of whether a nondangerous person receiving trealment could be confined indefinitely. Id. at 573 . Chief Justice Burger criticized the majority for avoiding the issue, arguing that the question of the reach of the parens patriae power was independent of what, if any, treatment is provided, and that parens patriae commitments can only be justified in cases where a person is unable to function in society and would suffer real harm if not placed in a sheltered environment. Id. at 583-84 (Burger, C.J., concurring).

Under either view in Donaldson, the LPS Act's substantive provision for 14-day certification of gravely disabled individuals is constitutional. The grave disability provisions are directed to nondangerous persons incapable of providing for the basic necessities of life, and the Act specifies that certifications for all patients are for "intensive treatment." CAL. WELF. \& INST. CODE $§ 5250$ (West 1972); see notes 34-37 supra and accompanying text.

82. 422 U.S. at 576 . Justice Stewart, writing for the majority, commented that "the mere presence of mental illness does not disqualify a person from preferring his home to the comforts of an institution." Id. at 575. 
Although the state has strong interests in protecting society and caring for those who cannot care for themselves, these interests do not seem sufficient to overcome the constitutional presumption in favor of protecting the individual's liberty. ${ }^{83}$ Nevertheless, even if general interest balancing favors a proposed procedural safeguard, the courts will not require the safeguard until other factors are examined. Due process analysis also considers the strength of the state's interests, the weight of the administrative burden imposed by a given safeguard, and the protection the safeguard affords to the individual. ${ }^{84}$ A closer examination of the certification process reveals that placing the burden on the state is appropriate even in light of these considerations.

The state engages in a form of preventive detention when it seeks to certify persons under the dangerousness standard. ${ }^{85}$ Because the mentally ill are the only group of potentially dangerous persons subject to preventive detention, the state should exercise this power cautiously. This is especially important because the mentally ill are not dangerous per se, ${ }^{86}$ and dangerousness is difficult to predict. ${ }^{87}$ Thus,

83. See notes 73-82 supro and accompanying text.

84. "The Court has repeatedly emphasized that determination of the constitutionally required procedural safeguards in any situation requires recognition both of the interests affected' and of the 'circumstances involved' . . . ." In re Gault, 387 U.S. 1, 69 (1967) (Harlan, J., concurring in part and dissenting in part). These circumstances include the strength of the state's interests, Morrissey v. Brewer, 408 U.S. 471, 483 (1972), and the practical effect of requiring a given safeguard, see Goss v. Lopez, 419 U.S. 565, 578 (1975).

85. Overt attempts to extend preventive detention to other groups have been sharply criticized, see Tribe, An Ounce of Detention: Preventive Justice in the World of John Mitchell, 56 VA. L. REv. 371, 385-90 (1970), and such detention is not generally authorized by law although it may exist in fact, Note, Preventive Detention: An Empirical Analysis, 6 HARV. C.R.-C.L. L. Rev. $300,346-47$ (1971). The mentally ill are not a suspect class for the purposes of the equal protection clause, see Note, Mental Illness: A Suspect Classification?', 83 YALE L.J. 1237 (1974), but the effect of civil commitment on fundamental rights may require a compelling state interest to justify detention. The classification does not appear to have even a rational basis, however, for the mentally ill as a class are no more dangerous to society than other individuals. Developments-Civil Commilment, supra note 2, at 1229-31; see note 87 infra and accompanying text.

86. See A. STONE, supra note 70 , at 27 (at most, $10 \%$ of hospitalized mentally ill persons are actually dangerous); note 87 infra and accompanying text.

87. Determining society's interest in protecting itself from the "dangerousness" of a given person requires answers to three different and very difficult questions: (1) Who is likely to cause harm? (2) What form is that harm likely to take? (3) When is the harm likely to occur? The difficulty of these questions has meant that the civil commitment process makes little effort to predict with any precision the likely danger of any prospective patient. See Ennis \& Litwack, supra note 68, at 711-16. The primary problem is that psychiatrists and psychologists "over-predict" or make "false-positive" errors. Present psychological techniques for predicting violence err in at least $60-70 \%$ of all cases: At least 6 out of 10 persons declared dangerous will cause no actual harm. Id. at 714. Even if predicting violent behavior were $95 \%$ accurate, a large number of persons who will never perform violent acts will be commit- 
the state should not be permitted to certify individuals on the basis of dangerousness without having to justify its action in court, for the probability that a particular person is dangerous in fact is very low. ${ }^{88}$ Similarly, under the "gravely disabled" standard, the state is likely to commit great numbers of people who are simply mentally ill or perhaps nuisances to their families or others, but who are capable of caring for their daily needs. ${ }^{89}$

Moreover, placing the burden of proof on the state would create practical benefits for the individual that easily outweigh any administrative burden the state is likely to bear. The state is the party invoking the certification process, and has the monetary resources and expert medical witnesses to bear the burden in screening and litigating certifications. On the other hand, a certified individual usually has no independent experts to testify in his behalf, and comes to court already labeled as mentally ill by virtue of having been certified. ${ }^{90}$ Furthermore, the person must overcome the judge's likely reluctance to contravene the judgment of the hospital psychiatrists by ordering the person's release. ${ }^{91}$

Both the theoretical and practical considerations in due process

ted as dangerous. Livermore, Malmquist \& Meehl, supra note 70, at 84-85. But see Monahan, Prediction Research and the Emergency Commilment of Dangerous Mentally Ill Persons: A Reconsideration, 135 AM. J. PsYcH. 198 (1978) (stating research in institutional settings cannot be generalized to "emergency" situations).

Suicide is also difficult to predict. See Greenberg, Involuntary Psychialric Commitments to Prevent Suicide, 49 N.Y.U. L. REv. 227, 259-63 (1974) (review of literature on prediction of suicide). But see Comment, Civil Commilment in California: 1969 Style, supra note 13, at 94-95 (prior suicide attempts place an individual in a high-risk category and may justify intervention).

88. See note 87 supra and accompanying text.

89. See O'Connor v. Donaldson, 422 U.S. 563 (1975); A. STONE, supra note 70, at $46 ;$ cf. Olmstead v. United States, 277 U.S. 438, 479 (1928) (Brandeis, J., dissenting) ("Experience should teach us to be most on our guard to protect liberty when the Government's purposes are beneficent. . . . The greatest dangers to liberty lurk in insidious encroachment by men of zeal, well-meaning but without understanding.").

90. See ENKI Research InStitute, supra note 13, at 184; Dilemma of Mental COMMTTMENTS, supra note 19 , at $40-43$.

91. Judges seldom have much knowledge of mental illness and often will defer to psychiatric experts. Bazelon, Institutional Psychialy-"The Self-Inficled Wound," 23 CATH. U.L. REV. 643 (1974); Hiday, Reformed Commilment Procedures: An Empirical Study in the Courtroom, 11 LAW \& SOC'Y REv. 651, 655 (1977); Hoffman \& Foust, Least Restrictive Treatment of the Mentally Ill: A Doctrine in Search of Ils Senses, 14 SAN Diego L. REv. 1100, 1137 \& Table X (1977). Moreover, humanitarian motives may influence judges to approve involuntary hospitalizations when a person is in need of some type of treatment, even when hospitalization is unnecessary. See ENKI RESEARCH INSTITUTE, supra note 13, at 184; Hoffman \& Foust, supra, at 1136. Finally, judges may be concerned about releasing "dangerous" individuals, and, like doctors, may prefer to err on the side of caution and approve the commitment. See Ennis \& Litwack, supra note 68, at 711, 729; Hiday, supra, at 655. 
analysis argue for an explicit assignment of the burden of proof to the state. Presently, judges at certification hearings face the dilemma of either placing the burden on the individual in violation of due process, or placing it on the state in contravention of the statutory provision that the hearing is a habeas corpus proceeding. The current uncertainty about the allocation of the burden of proof also has blurred the adversarial nature of the hearing, leaving many attorneys representing certified individuals confused about their appropriate roles as counsel. ${ }^{92}$ The legislature can resolve these problems by amending the LPS Act, making it clear that the state bears the burden of proof.

\section{The Standard of Proof in Certification Hearings}

Shifting the burden of proof to the state in certification hearings helps protect the constitutional rights of persons facing 14 days of involuntary hospitalization. But that protection is incomplete without a determination of the proper weight to assign that burden-the standard of proof. The LPS Act never mentions a standard of proof for certification hearings. Courts would therefore appear justified in applying the standard of a preponderance of the evidence, since the California Evidence Code prescribes that standard in any adjudication for which no other standard is expressly provided by statute or court decision. ${ }^{93}$

Nevertheless, it may be hasty to assume that the drafters of the LPS Act deliberately incorporated the general preponderance rule. Rather, as with the question of burden of proof, the drafters' silence on the standard of proof issue may represent either inadvertence, or deliberate avoidance as part of the delicate political compromise that made enactment of the LPS Act possible. ${ }^{94}$ The requirements of due process demand that the law clearly and consciously assign the standard of proof after consideration of the strong individual and state interests affected by any particular standard.

92. Attorneys in civil commitment proceedings often do not see themselves in the traditional role of adversaries. Some ignore or discount their client's wishes and acquiesce in the commitment, see Wexler \& Scoville, The Administration of Psychiatric Justice: Theory and Practice in Arizona, 13 ARIZ. L. REV. 1, 52-54 (1971), and those who do not still may be uncertain of their precise role. See, e.g., Cohen, The Function of the Altomey and the Commitment of the Mentally IIl, 44 TEx. L. REv. 424 (1966); Monahan, Empirical Analyses of Civil Commitment: Critique $\mathfrak{F}^{\circ}$ Context, 11 Law \& Soc'y REv. 619,623-24 (1977); Note, The Role of Counsel in the Civil Commitment Process: $A$ Theoretical Framework, 84 YALE L.J. 1540 (1975).

93. Gal. Evid. CoDE $§ 115$ (West 1966).

94. See notes $46-48$ supra and accompanying text. 
The courts and legislatures initially have a wide choice of standards, ranging from the least exacting standard of probable cause, to preponderance of the evidence, to clear and convincing evidence, to the most exacting standard of proof beyond a reasonable doubt. ${ }^{95}$ Although the distinctions among these standards may appear elusive in the abstract, ${ }^{96}$ they may become critical in practice. Depending on the circumstances of a given proceeding, a small change in the standard of proof may tip the balance in favor of one party or the other. As a result, courts frequently have adjusted the standard of proof upwards in proportion to the severity of the consequences of an erroneous decision in a particular type of proceeding. ${ }^{97}$

As in the determination of the assignment of the burden of proof, determining the proper standard of proof requires not only a balancing of individual and state interests, but also a subtle analysis of the practical considerations in a given type of proceeding. A starting point in the analysis for certification hearings is an examination of the standard of proof question in the closely related area of long-term commitments.

\section{A. The Standard of Proof in Long-Term Civil Commitment}

Recent court examination of the standard of proof in long-term civil commitment hearings is founded on the general constitutional development of the standard of proof in cases involving serious deprivations of individual liberty. In 1970, the United States Supreme Court held in In re Winship that due process requires proof beyond a reasonable doubt in criminal and juvenile delinquency proceedings. ${ }^{98}$ The Court first referred ${ }^{99}$ to the initial balance of individual and state interests it had struck 3 years earlier in $I n$ re Gault ${ }^{100}$ Gault had held that the requirements of procedural due process applied to juvenile delinquency hearings because of their effect on individual liberty. The Court in Winship extended its analysis in Gault by holding that in criminal and juvenile delinquency proceedings, the indi-

95. For a general discussion of standards of proof, see C. MCCORMICK, HANDBOOK OF THE LAW OF EVIDENGE $\S \S 339-341$ (2d ed. 1972).

96. See id. §339.

97. See, e.g., People v. Burnick, 14 Cal. 3d 306, 535 P.2d 352, 121 Cal. Rptr. 488 (1975) (California Supreme Court noting that "mentally disordered sex offender" could be committed for life, but required proof beyond reasonable doubt; reversing decision applying preponderance of evidence standard).

98. 397 U.S. $358,364,368$ (1970).

99. Id. at $365-66$.

100. 387 U.S. 1 (1967) (in juvenile delinquency proceedings, child's interest in liberty warrants safeguards of notice, counsel, confrontation, privilege against self-incrimination, and written record). 
vidual's interest in personal liberty and freedom from stigma, combined with society's interest in preserving the freedom and good name of the individual, outweigh the state's interests in punishment, protection of society, and rehabilitation. ${ }^{101}$ In requiring the standard of proof beyond a reasonable doubt in such proceedings, the Court incorporated into its analysis a consideration of society's values and the practical results flowing from the use of a particular standard of proof in the proceedings under review. ${ }^{102}$

Many courts have used Winship as a basis for requiring the standard of proof beyond a reasonable doubt in long-term civil commitment hearings. ${ }^{103}$ The District of Columbia Circuit Court of Appeals relied on Winship's extension of the standard of proof beyond a reasonable doubt from criminal to juvenile proceedings in In re Ballay. ${ }^{104}$ The court, instead of analyzing the issue on general due process grounds, compared the state and individual interests at stake in civil commitment proceedings with those in criminal cases. ${ }^{105}$ The court found the state interests in civil commitments were no greater than

101. 397 U.S. at $365-68$.

102. See id. at 366-67 (strict standard of proof would not put undue practical burden on state); id. at 375 (Harlan, J., concurring) (same).

103. In re Ballay, 482 F.2d 648 (D.C. Cir. 1973); Suzuki v. Quisenberry, 411 F. Supp. 1113 (D. Haw. 1976); Davis v. Watkins, 384 F. Supp. 1196 (N.D. Ohio 1974); Lessard v. Schmidt, 349 F. Supp. 1078 (E.D. Wis. 1972), vacated and remanded on other grounds, 414 U.S. 473, on remand, 379 F. Supp. 1376 (E.D. Wis. 1974), vacated and remanded on other grounds, 421 U.S. 957 (1975), reinstaled, 413 F. Supp. 1318 (1976); Superintendent v. Hagberg, 78 Mass. Adv. Sh. 187, 372 N.E.2d 242 (1978); Lausche v. Commissioner of Pub. Welfare, 302 Minn. 65, 225 N.W.2d 366 (1974) (dictum), cert. denied, 420 U.S. 993 (1975); Proctor v. Butler, N.H. -, 380 A.2d 673 (1977); State v. O'Neill, 274 Or. 59, 545 P.2d 97 (1976); cf. In re Levias, 83 Wash. 2d 253, 517 P.2d 588 (1973) (clear, cogent, and convincing evidence civil analogue to proof beyond a reasonable doubt). The Kentucky Court of Appeals held that proof beyond a reasonable doubt is required in civil commitment proceedings well before Winship was decided. Denton v. Commonwealth, 383 S.W.2d 681 (Ky. 1964).

At least eight states have statutes requiring the use of the standard of proof beyond a reasonable doubt for some elements in long-term civil commitment proceedings. Haw. REV. STAT. § 334-60(b)(4)(I) (Supp. 1978) (mentally ill, dangerous to self or others or in need of treatment, and no less restrictive alternative available); IDAHO CODE $§ 66-329$ (i) (Supp. 1978) (mentally ill or retarded, or likely to injure self or others); KAN. STAT. \$ 59-2917 (1976) (mentally ill); MONT. REv. CoDes ANN. § 38-1305(7) (Supp. 1977) (any physical facts or evidence); OKLa. Stat. ANN. tit. 43A, §54.1(C) (West Supp. 1977) (mentally ill and either dangerous to self or others or unable to care for self); OR. REV. STAT. $\S 426.130$ (1977) (mentally ill); UTAH CODE ANN. §64-7-36(6) (1978) (mentally ill, no less restrictive alternative, and either immediate danger to self or others or unable to care for self); WIS. STAT. ANN. \$ 51.20(12) (West Supp. 1978) (mentally ill and either dangerous to self or others or unable to care for self).

104. 482 F.2d 648 (D.C. Cir. 1973). Ballay had been committed under a statute providing indefinite commitment of persons dangerous to themselves or others. Id. at $649 \mathrm{n} .2$.

105. Id. at 657-58. 
those in criminal cases, ${ }^{106}$ and that the individual interests in civil commitments were if anything greater. ${ }^{107}$ The court expressly rejected the argument that the ostensibly beneficial purpose of involuntary hospitalization argued for a standard of proof lower than that of beyond a reasonable doubt. ${ }^{108}$

The California Supreme Court has reached different results on the issue of the standard of proof depending on the grounds for commitment. In People v. Burnick, ${ }^{109}$ the court followed Winship and Ballay in holding that the stigma and indefinite loss of liberty resulting from commitment as a mentally disordered sex offender (m.d.s.o.) required the standard of proof beyond a reasonable doubt in m.d.s.o. proceedings. ${ }^{10}$ The court later extended this requirement to commitments of narcotics addicts. ${ }^{11}$

In 1978, however, in In re Estate of Roulet, ${ }^{12}$ the California court declined to require the strict standard of proof in l-year commitments for grave disability. The majority based its rejection of the standard of proof beyond a reasonable doubt on the civil nature of the commitments, the likelihood that society would view the gravely disabled with compassion, and the definite time limitation on the commitment. ${ }^{13}$ The majority reasoned that because commitments for grave disability were for the individual's benefit, the analogy to criminal confinement was inappropriate. ${ }^{114}$ They acknowledged that the individual's interest in personal liberty would receive inadequate protection under the preponderance standard, however, and struck a middle ground by holding that the proper standard was that of clear and convincing evidence. ${ }^{115}$ Other courts have reached the same

106. Id.

107. Id. at 668-69 (stressing that mental patients, unlike criminals, can be detained indefinitely, and danger of patients after release suffering social ostracism, employment discrimination, and self-labeling detrimental to their health).

108. Id. at 667 (noting that "beneficial" hospitalization can seriously harm patients).

109. 14 Cal. 3d 306, 535 P.2d 352, 121 Cal. Rptr. 488 (1975).

110. Id. at $324-25,535$ P.2d at 364, 121 Cal. Rptr. at 500 .

111. People v. Thomas, 19 Cal. 3d 630, 566 P.2d 228, 139 Cal. Rptr. 594 (1977).

112. 20 Cal. 3d Adv. Sh. 653, 574 P.2d 1245, 143 Cal. Rptr. 893, rehearing granted, 20 Cal. 3d 653 (1978).

113. Id. at $659-60,574$ P.2d at 1249,143 Cal. Rptr. at 897.

114. Id.

115. Id. at 660-61, 574 P.2d at 1249, 143 Cal. Rptr. at 897-98. The majority held that the preponderance standard would "fail to adequately safeguard the individual's rights" and that " $[t]$ his potential deprivation of liberty dictates a higher standard of proof be used to minimize risk of error." The beyond-a-reasonable-doubt standard, on the other hand, "may ... prevent individuals from receiving sorely needed aid. . . [A]n individual may quite literally be left to languish in the streets. Application of the criminal standard would threaten the beneficial statutory purpose . . ." Id. at 661,574 P.2d at 1249,143 Cal. Rptr. at 897-98. 
conclusion. ${ }^{116}$

The Roulet dissent, written by Chief Justice Bird, insisted that the majority was contradicting the decisions of the United States Supreme Court in Winship and Gault which explicitly stated that the distinction between civil and criminal proceedings is irrelevant to a determination of due process requirements. ${ }^{117}$ The dissent pointed out that the compassion towards the gravely disabled envisioned by the majority was at odds with the reality of the stigma experienced by most former mental patients. ${ }^{18}$ Winship and the California court's holdings in Burnick and other cases mandated the use of the beyond-a-reasonable-doubt standard when a finding adverse to the individual resulted in stigma and a deprivation of liberty. The court granted a rehearing in Roulet, ${ }^{119}$ and a change in the court's membership created majority support for Chief Justice Bird's position. ${ }^{120}$

The United States Supreme Court will decide this term whether the constitutional minimum in long-term civil commitment proceedings is proof beyond a reasonable doubt, clear and convincing evidence, or proof by a preponderance. ${ }^{121}$ The consensus of jurisdictions is that long-term commitments require the standard of proof beyond a reasonable doubt or clear and convincing evidence. This choice of standards from the upper range of the four theoretical choices for long-term civil commitment provides a basis for examining the appropriate standard for short-term commitment proceedings.

\section{B. Long-Term and Short-Term Commitments: A Comparison of the Interests Relevant to the Selection of the Standard of Proof}

With the standards of proof beyond a reasonable doubt or clear and convincing evidence established as a yardstick for long-term

116. Stamus v. Leonhardt, 414 F. Supp. 439 (S.D. Iowa 1976); Doremus v. Farrell, 407 F. Supp. 509 (D. Neb. 1975); In re Stephenson, 67 Ill. 2d 544, 367 N.E.2d 1273 (1977); In re Valdez, 88 N.M. 338,540 P.2d 818 (1975).

117. See notes $98-102$ supra and accompanying text.

118. In re Estate of Roulet, 20 Cal. 3d Adv. Sh. 653, 669-71, 574 P.2d 1245, 1255-56, 143 Cal. Rptr. 893, 903-04 (Bird, C.J., dissenting), rehearing granted, 20 Cal. 3d 653 (1978).

119. 20 Cal. 3d 653 (1978).

120. Justice Frank Newman joined the original dissenters in holding that proof beyond a reasonable doubt is required. In re Estate of Roulet, S. F. Chronicle, Feb. 7, 1979, at 6, col. 6.

121. State v. Addington, 557 S.W.2d 511 (Tex. 1977), prob. juris. noted, 435 U.S. 967 (1978) (No. 77-5992). Even were the Court to approve the preponderance standard as a minimum, the states will remain free, through legislation or judicial interpretation of their own constitutions, to retain either of the higher standards as the appropriale one for long-term civil commitment. 
commitments, a comparison of the relative interests of the state and the individual in the short-term context helps to focus on the appropriate standard in certification proceedings.

\section{The individual's interest in a high standard.}

Part II of this note demonstrates that the individual interests at stake in both long-term commitments and certifications are considerable. Either form of commitment will result in a loss of personal liberty, ${ }^{122}$ stigma, ${ }^{123}$ unwanted medical treatment, ${ }^{124}$ and future legal disabilities. ${ }^{125}$ Nevertheless, the difference in length of the imposed hospitalization permits some distinction between the two forms of commitment. Certification for 14 days is not likely to cause the psychological phenomenon of "institutionalization,"126 a common result of long-term confinement which is characterized by apathy and an inability to function outside of the institutional environment. ${ }^{127}$ Certifications also have a definite and easily foreseeable end; the individual has relative assurance of the right to a full trial before the state may confine him for an additional period. ${ }^{128}$ Furthermore, certifications are less likely to disrupt an individual's life, because unlike long-term patients who are placed in state hospitals at a considerable distance from family and friends, certified persons are usually hospitalized near their homes. ${ }^{129}$ Individuals do suffer significantly as a

122. See notes 59-63 supra and accompanying text.

123. See notes 64-68 supra and accompanying text.

124. See notes 69-72 supra and accompanying text.

125. The LPS Act does provide that persons may not be presumed incompetent for the purpose of imposing legal disabilities on them simply because they have been certified, CAL. WELF. \& INST. CODE $§ 5331$ (West Supp. 1978), but a finding of mental illness or grave disability would be relevant to determinations of competency. See In re Estate of Roulet, 20 Cal. 3d Adv. Sh. 653, 669, 574 P.2d 1245, 1254-55, 143 Cal. Rptr. 893, 902-03 (Bird, C.J., dissenting), rehearing granted, 20 Cal. 3d 653 (1978).

126. Although the precise time necessary for a person to become "institutionalized" has never been determined, short-term commitment for a maximum of 20 days is unlikely to produce institutionalization. Institutionalization is not always inevitable and probably varies in severity from individual to individual. For example, Kenneth Donaldson lived in a mental hospital for 15 years and apparently escaped institutionalization during that time. But he is exceptional and, even for him, adjustment to "living on the outside" again required effort. See K. DONALDSON, supra note 60.

127. E. GoffmaN, supra note 59, at 146-69; Chambers, supra note 59, at 1127-29.

128. The assurance of release or trial at the end of the 14-day certification is not complete, however. The individual may be recertified for an additional 14 days or placed on a temporary conservatorship, neither of which requires a full trial, although both these devices provide for habeas corpus hearings, CAL. WELF. \& INST. CODE $\S 5262 \& 5263,5350$ \& 5352.1 (West 1972 \& Supp. 1978).

129. The LPS Act's 14-day certification procedure was designed in part to provide hospitalization near the individual's residence, Dilemma of MenTal Commrtments, supra note 19 , at $90-92$, so the individual would find it less difficult to return to his home. Id. at 64 . 
result of certification, but probably escape the most drastic consequences of long-term hospitalization.

\section{The state's interest in a low standard.}

The state's general interests in certification, protecting society ${ }^{130}$ and caring for incapacitated persons ${ }^{131}$ also apply to long-term commitments, but certifications also serve a distinct purpose in the state's general mental health system. The legislature intended certifications to allow for crisis intervention and treatment of the mentally ill without immediately subjecting them to long-term commitment. ${ }^{132}$ Doctors were to have as much as 20 days in which to aid acute patients with a minimum of legal interference. ${ }^{133}$ The legislature believed, and prevailing medical opinion indicated, that short-term state intervention is helpful in alleviating acute mental distress, protecting others from harm, and preventing suicides. ${ }^{134}$ These distinct purposes may argue against the use of the same standard of proof in certification hearings as in long-term commitment proceedings, because a high standard would increase judicial scrutiny and potentially undermine the state's special interests in the certification process.

\section{Reconciling the Interests: Setting the Standard for Short-Term Commitments}

The comparison of the relative individual and state interests in long-term and short-term commitments does not diminish the need to protect the individual's interests in certification hearings, but it does suggest that a somewhat lower standard of proof might be appropriate in these proceedings. The inferences that might be drawn initially from the comparison are that the standard of proof beyond a reasonable doubt, the higher of the two standards commonly required in long-term commitment proceedings, is inappropriate for short-term commitment hearings, and that the lowest possible standard of probable cause is also improper because of the need to protect the important individual interests at stake. The choice of a standard for certification hearings may lie somewhere between these

130. See notes 73-76 supra and accompanying text.

131. See notes 77-82 supra and accompanying text.

132. Dilemia of Mental Commitments, supra note 19, at 137-38; ENKI RESEARCH INSTITUTE, supta note 13, at 15.

133. See notes 46-47 supra and accompanying text.

134. See, e.g., A. STONE, supra note 70 , at 64 . 
two extremes with either the standard of preponderance of the evidence or clear and convincing evidence. Keeping these initial inferences in mind, this section canvasses all four possible standards of proof in light of their practical consequences.

\section{Proof beyond a reasonable doubt.}

The standard of proof beyond a reasonable doubt requires the factfinder to be as certain as humanly possible that the party bearing the burden of proof should prevail. ${ }^{135}$ The courts have been less than unanimous in mandating the use of this strict standard of proof even in long-term commitment proceedings, indicating that it may not be the appropriate standard in certification hearings. The Supreme Court's view that the length and severity of deprivations of liberty are factors to be weighed in determining the nature of a hearing ${ }^{136}$ combines with important practical factors and societal values to weigh heavily against the use of the strict standard in certifications.

At some point, adding more procedural safeguards to a proceeding makes it so cumbersome and renders so little additional benefit to the individual that the balance tips against requiring the proposed safeguard. ${ }^{137}$ Requiring proof beyond a reasonable doubt in certification hearings may raise just this problem. The state often has only 3 days to determine the need to certify an individual, and only 4 days to evaluate the person before the certification hearing is held. This is probably not enough time to gather sufficient evidence to overcome reasonable doubts, ${ }^{138}$ and the cost of a full investigation of an indi-

135. See Tribe, Trial by Mathematics: Precision and Ritual in the Legal Process, 84 Harv. L. REV. 1329, 1374 (1971). Simon and Mahan found one-third of the judges they surveyed indicated proof beyond a reasonable doubt requires $100 \%$ certainty, one-third stated it requires $90-95 \%$ certainty, and the remaining third stated the requisite certainty is $80 \%$ or slightly less. Simon \& Mahan, Quantiffing the Burdens of Proof, 5 LAW \& Soc'Y REv. 319, 324 (1971).

136. See, e.g., Goss v. Lopez, 419 U.S. 565, 576 (1975) (short suspension from school milder than expulsion, but 10 days serious enough to warrant some procedural safeguards); Morrissey v. Brewer, 408 U.S. 471, 484-88 (1972) (conditional liberty interest of parolees requires due process safeguards but hearing can be informal). The cases incorporating the safeguards of the Bill of Rights in the 14th amendment suggest that both the length of deprivation of liberty resulting from a proceeding and the history of a procedure help determine the importance of a given safeguard. Compare Duncan v. Louisiana, 391 U.S. 145 (1968) (right to jury trial for crimes with sentences greater than 6 months; no common law tradition of juries in petty cases), with Argerslinger v. Hamlin, 407 U.S. 25 (1972) (right to counsel in all criminal cases, since no traditional exception for petty crimes). This approach would argue against the use of the same strict standard in short-term as in long-term commitments, especially because there is no "traditional" standard in either form of commitment.

137. Friendly, "Some Kind of Hearing," 123 U. PA. L. Rev. 1267, 1276 (1975).

138. A person may need several days to adjust to the hospital, see E. GofFMAN, supra note 59 , at $148-49$, before he can be realistically evaluated. The state would have to increase 
vidual prior to certification in order to sustain the heavy burden of proof would be prohibitive in many instances.

Moreover, because a hearing must be held within 2 court days of an individual's request, ${ }^{139}$ counsel, doctors, and other witnesses have only a short time in which to prepare. ${ }^{140}$ On such short notice, the certifying psychiatrist may not be available to testify at all. Without much time to prepare and potentially without the testimony of the physician most familiar with the individual, the state may never be able to meet the standard of proof beyond a reasonable doubt. ${ }^{141}$

Finally, there must be a full trial on the issues if the state decides to initiate long-term commitment at the end of the certification period. ${ }^{142}$ But if the state has recently demonstrated that a person is mentally ill and dangerous, or gravely disabled beyond a reasonable doubt, the results of a subsequent trial may be foreordained. ${ }^{143}$ Thus, the individual might actually suffer more in the long run if he has been certified under the beyond-a-reasonable-doubt standard.

The beyond-a-reasonable-doubt standard is inappropriate for certification hearings. Given the slightly less serious impact of short-

the size of the professional staff of hospitals to provide for sufficient observation and testing within a short period. Although this would be the best result in any case, state hospitals, at least, are already badly understaffed. See McManus \& Horowitz, Cruel and Usual Punishment, New West, June 5, 1978, at 39.

139. See note 42 supra and accompanying text.

140. In Santa Clara County, for example, certification hearings are held on Tuesdays and Fridays. Both county counsel representing the state and public defenders representing individuals have little time in which to prepare for the hearings, especially if an individual requests a hearing on the same day as the hearings are scheduled. The public defender may not be able to meet with her client until he arrives at the courthouse and has virtually no time in which to investigate the situation fully. The same is true for the county counsel. Frequently while the county counsel are off in one corner outside the courtroom hurriedly leafing through hospital reports and talking to the doctors who will testify, the public defenders are in another corner interviewing their clients.

141. The ENKI study found that judges almost always released individuals in the absence of medical testimony at the hearings, even with the present confusion over the burden and standard of proof. ENKI RESEARCH INSTITUTE, supra note 13, at 181. The testimony of a doctor is undoubtedly critical to the state's case, see Ennis \& Litwack, supra note 68, at 694, and if the certifying psychiatrist cannot testify, the state will have to substitute with a doctor who usually bases her testimony on hospital records and a rushed interview with the petitioner. A few hurried notes would not be sufficient to meet the reasonable-doubt standard.

142. Cal. Welf. \& INST. Code $\S \S 5301$ to 5303, 5350 (West 1972 \& Supp. 1978). Trial would immediately follow the certification in the case of a post-certification for dangerousness to others. A delay of at least 30 days before trial is possible in the case of 1-year conservatorships. Id. $§ 5352.1$.

143. The fact and basis of the original certification might come into evidence at the commitment trial either as the basis of opinion of the testifying psychiatrist or through the state attorney's attempt to impeach the individual if he testifies at his trial. See CaL. Evid. CODE $§ \S 773,801$ (West 1966). 
term commitments on individuals, it is impossible to justify requiring a stricter standard of proof in certification hearings than is required in long-term commitment trials in many instances.

\section{Probable cause.}

"Probable cause" means reasonable grounds to believe something is true ${ }^{144}$ and rests at the other extreme on the continuum of standards. This standard does not demand much certainty on the part of the factfinder, and the risk of an erroneous determination against the individual is so high that the standard's protection of the individual's liberty interest is negligible. ${ }^{145}$ Probable cause seems attractive because of the analogy between certification hearings and preliminary hearings in criminal cases, in which the state must show probable cause to detain a person suspected of committing a crime. ${ }^{146}$ The analogy quickly diminishes upon closer examination: In criminal proceedings, a harm has already occurred, whereas in many certification hearings actual harm to society is not an issue. ${ }^{147}$ Moreover, criminal defendants can gain release from custody on bail or their own recognizance, while a certified person has no such opportunity to leave the hospital. ${ }^{148}$

Neither of the two extreme standards of proof is a workable solution to the problem of finding a standard of proof for certification hearings. Two standards remain as candidates: preponderance of the evidence and clear and convincing evidence.

144. A. Amsterdam, B. Segal \& M. Miller, Trial Manual for the Defense of Criminal Cases $\S 241$ (3d ed. 1977).

145. 'Probable cause findings often tend toward 'rubber-stamp' determinations. Assertions are often accepted at face value and inferences are generously drawn on the basis that only reasonable grounds need support the truth of the alleged facts." MHLP Proposal, supra note 5 , at 100 .

146. See, e.g., Gerstein v. Pugh, 420 U.S. 103 (1975); FED. R. CRIM. P. 5. The standard has been applied to short-term commitment hearings by a few courts, In re Barnard, $455 \mathrm{~F} .2 \mathrm{~d}$ 1370 (D.C. Cir. 1971); Lessard v. Schmidt, 349 F. Supp. 1078 (E.D. Wis. 1972), vacaled and remanded on other grounds, 414 U.S. 473 (1974), on remand, 379 F. Supp. 1376 (E.D. Wis. 1974), vacated and remanded on other grounds, 421 U.S. 957 (1975), reinslated, 413 F. Supp. 1318,(1976), and at least one legislature, WASH. REV. CODE ANN. § 71.05.240 (1975).

147. See notes 85-89 supra and accompanying text.

148. A. AmSTerdaM, B. Segal \& M. Miller, supra note 144, at \$§ 54-59. In California, defendants may be admitted to bail as a matter of right in all but capital cases, CAL. PENAL CODE § 1271 (West 1970), or released on their own recognizance, id. § 1318. Indigent defendants may not be able to make bail and others may not be eligible for release on their own recognizance, but these options remain available for many arrested people. Certified persons, however, must remain in the hospital unless a doctor permits them to leave. Sometimes an attorney may be able to persuade the hospital staff to release an individual by threatening to request a hearing. Interview with Steve Stevens, Santa Clara County Public Defender's Office, in San Jose (July 18, 1977). 


\section{Preponderance of the evidence.}

This standard is the standard of proof used in most civil actions. Preponderance of the evidence requires the factfinder to determine that the existence of a fact is more probable than not before he may find in favor of the party bearing the burden of proof. ${ }^{149}$ Logical symmetry might argue for the preponderance standard in certification hearings: The individual's interests at stake in certification proceedings are not as strong as those in long-term commitments, and a lower standard than proof beyond a reasonable doubt or clear and convincing evidence might seem appropriate. ${ }^{150}$ Such an analysis, however, fails to account for either important values or practical realities. While in a contract dispute, for example, "we view it as no more serious . . . for there to be an erroneous verdict in the defendant's favor than for there to be an erroneous verdict in the plaintiff's favor," 151 an erroneous verdict is a grave matter when an individual's liberty and good name are at stake. The preponderance standard simply does not provide adequate protection of those interests, because of its intrinsic mathematical indifference to the outcome.

In practical terms, the preponderance standard would actually tip the balance slightly against the individual in certification hearings. In a typical hearing, the state presents expert testimony that the individual suffers from a mental disorder and is dangerous or gravely disabled. ${ }^{152}$ Then the individual testifies to the effect that he is none of these things. ${ }^{153}$ Understandably, the judge in many in-

149. C. MCCORMICK, supra note 95 , at $\S 339$. When asked to state the degree of certainty necessary to find for the party bearing the burden under this preponderance standard, over one-half of the judges in one study said the requisite probability was $55 \%$. Simon \& Mahan, supra note 135 , at 325 .

150. The Supreme Court rejected the argument that deportation proceedings need only be resolved by a preponderance of the evidence because they were civil in nature, stating, "To be sure, a deportation proceeding is not a criminal prosecution . . . . But it does not syllogistically follow that a person may be banished from this country upon no higher degree of proof than applies in a negligence case." Woodby v. Immigration \& Naturalization Serv., 385 U.S. 276, 285 (1966) (drastic nature of deportation and effect on liberty requires proof by clear, convincing, and unequivocal evidence).

151. In re Winship, 397 U.S. 358, 371 (1970) (Harlan, J., concurring).

152. In a typical hearing in Santa Clara County, the only evidence proffered by the state is the testimony of a psychiatrist, who may or may not be the treating physician in the case. The psychiatrist testifies that a person is mentally ill and often is allowed to offer a conclusion that the person is dangerous or gravely disabled, although this question appears to be at least in part a question of fact. Warren's study indicates that psychiatric evidence of refusals to take medicine often resulted in a finding of grave disability. See Warren, supra note 13 , at 634-65.

153. The individual, unlike many psychiatrists, may never have participated in a court proceeding before. Any uncertainty or nervousness on the part of the individual is likely to be 
stances is likely to accord the psychiatrist's testimony slightly more weight than the testimony of an individual who somehow wound up in a mental hospital. Therefore, although the state would technically bear the burden of proof, a mere preponderance standard would effectively shift the burden back to the individual, in contravention of due process. ${ }^{154}$

Analysis of the available standards ultimately converges on the flexible standard that lies in between proof beyond a reasonable doubt and proof by preponderance: proof by clear and convincing evidence.

\section{Clear and convincing evidence.}

The standard of proof by clear and convincing evidence lies somewhere between the "slightly more probable" notion of the preponderance standard and the "as sure as humanly possible" concept of beyond a reasonable doubt. One commentator has stated that the standard of clear and convincing evidence requires a finding that the existence of a fact is "highly probable." 155 The standard is especially responsive to the policies at issue in a given proceeding, allowing for adjustment to the specific consequences of the proceeding. ${ }^{156}$

The Supreme Court has recognized that due process can require the use of the clear and convincing standard in proceedings that have a substantial effect on personal liberty. In Woodby $v$. Immigration $\mathfrak{G}^{\circ}$

perceived by the judge as evidence of mental illness in light of what the psychiatrist has already said. Often, no matter what evidence is presented, the judge will simply refuse to believe the individual. Hearing of July 19, 1977, supra note 37.

154. See Part II supra.

155. C. MCCORMICK, supra note 95 , at $\$ 340$. In holding that the standard of clear and convincing evidence is required in long-term civil commitment proceedings, the New Mexico Supreme Court noted, "For evidence to be clear and convincing, it must instantly tilt the scales in the affirmative when weighed against the evidence in opposition and the fact finder's mind is left with an abiding conviction that the evidence is true." In re Valdez, 88 N.M. 338, 343, 540 P.2d 818, 823 (1975) (quoting In re Sedillo, 84 N.M. 10, 12, 498 P.2d 1353, 1355 (1972)).

156. See Alsager v. District Court, 406 F. Supp. 10, 25 (D. Iowa 1975) (court must look to nature of right involved to determine proper standard of proof). The California courts have followed Alsager, a juvenile case, in a series of decisions involving the standard of proof for finding a child to be a dependent ward of the court. Despite clear statutory language establishing preponderance of the evidence as the standard in findings of dependency, CAL. WELF. \& INST. CODE $\S 355$ (West Supp. 1978), the courts have used their discretion to adjust the standard of proof to the severity of the disposition likely to follow from a dependency finding. Compare In re Robert P., 61 Cal. App. 3d 310, 318, 132 Cal. Rptr. 5, 10 (1st Dist. 1976) (clear and convincing evidence where finding will deprive parent of custody), with In re Christopher B., 82 Cal. App. 3d 608, 617-18, 147 Cal. Rptr. 390, 395 (3d Dist. 1978) (preponderance where finding will only result in supervision of parent). 
Naturalization Service ${ }^{157}$ the Court acknowledged that a deportation proceeding is different from a criminal prosecution, but recognized the "drastic deprivations" of liberty resulting from deportation. The Court found the standard of clear and convincing evidence particularly useful in its protection of individual interests and its flexible response to the circumstances of a given case. ${ }^{158}$

The intermediate standard of clear and convincing evidence ensures judicial protection of the individual's interests while recognizing the reasonable limits of time and resources faced by the state in certification hearings.

\section{The Clear and Convincing Evidence Standard in Practice}

The burden of proving by clear and convincing evidence that an individual is gravely disabled or dangerous as a result of a mental disorder is not unduly onerous for the state. The 72 hours (or more) during which the person is in the hospital before certification gives the staff adequate time to determine that it is "highly probable" that the person is suffering from a mental disorder, the threshold question in a certification hearing. ${ }^{159}$

The other substantive grounds for certification do not present inordinate problems of proof under the clear and convincing standard. In showing "grave disability," testimony on the certified individual's ability to provide food, clothing, or shelter should be readily available if the person is truly within the statutory provision: The standard simply requires that the judge be satisfied that the individual is unable to provide for himself. A psychiatrist's general assertion that a person has "poor judgment" in his eating habits, while likely to persuade a judge to uphold the certification under the preponder-

157. 385 U.S. 276 (1966).

158. "This Court has not closed its eyes to the drastic deprivations that may follow when a resident of this country is compelled by our Government to forsake all the bonds formed here and go to a foreign land where he often has no contemporary identification. In words apposite to the question before us, we have spoken of 'the solidity of proof that is required for a judgment entailing the consequences of deportation, particularly in the case of an old man who has lived in this country for forty years . . . ' " Id. at 285 (quoting Rowoldt v. Perfetto, 355 U.S. 115, 120 (1957)); see Chaunt v. United States, 364 U.S. 350 (1960) (clear and convincing evidence standard required to revoke naturalization); Nishikawa v. Dulles, 356 U.S. 129 (1958) (same in expatriation proceeding).

159. Although diagnostic accuracy is questionable even under ideal conditions, an individual's behavior over a few days should indicate whether he suffers from a mental disorder or not. See, e.g., Morse, Crazy Behavior, Morals, and Science: An Analysis of Mental Health Law, $51 \mathrm{~S}$. CAL L. REV. 527 (1978). The clear and convincing standard simply suggests to psychiatrists that they must be more certain of their evaluations than they need be at present and that they have an objective basis for their evaluations. 
ance standard, would not be sufficient to constitute the high probability that the person cannot provide for food required under the clear and convincing standard. ${ }^{160}$ But, evidence that a person has not eaten for days before hospitalization, or is suffering from malnutrition, can be obtained and probably would meet the clear and convincing test. ${ }^{161}$

"Dangerousness to self or others" is difficult to prove under any standard. The difficulty of predicting violent or suicidal behavior under even the best diagnostic conditions ${ }^{162}$ makes it almost as difficult for the state to meet the preponderance standard, if fairly applied by the judge, as it would be to meet the clear and convincing standard. ${ }^{163}$ On the other hand, if the state does have reliable evidence of the person's assaultive behavior or of a genuine suicide attempt, the clear and convincing evidence standard should not be a serious obstacle to certification. ${ }^{164}$

160. "Poor judgment" is frequently invoked by psychiatrists testifying in Santa Clara County certification hearings. It is difficult to know precisely what the term means, because it is used to refer to absence of judgment, judgment differing from that of the psychiatrist, or simply a few erroneous decisions. The phrase has a normative quality that may often reflect an educational or class bias. See Braginsky \& BRaginsky, Mainstream Psychology: A Critique (1974); P. Chesler, Women and Madness (1972); B. Dohrenwend \& B. Dohrenwend, Social Status and Psychological Disorder: A Causal INQuiry (1969); A. Hollingshead \& F. Redligh, Social Class and Mental Illness (1958). For example, a diet consisting largely of rice, tortillas, and beans might be regarded as insuffciently nutritious by a psychiatrist because it lacks green vegetables and fruits; a person whose diet consisted of these foods might be said to have "poor judgment" about food. If the person were a poor Mexican-American, however, his judgment about nutrition would be perfectly normal and "sane." The clear and convincing standard would caution a judge to take such things into account in making his decision. At least such a test would limit the discretion that currently permits judges to find individuals gravely disabled on the grounds, for example, that a person's home was dirty. See Warren, supra note 13, at 638 .

161. This is essentially a factual question and can be addressed by witnesses who are not psychiatric experts. See Morse, supra note 159, at 616.

162. See note 87 supra and accompanying text.

163. See Monahan \& Wexler, A Defnile Maybe: Proof and Probability in Civil Commilment, 2 LAw \& HUMAN BeHAVIOR 37 (1978). Several courts have asserted that the difficulty of proving dangerousness argues for a lower standard of proof than beyond a reasonable doubt. See, e.g., In re Stephenson, 67 Ill. 2d 544, 555-56, 367 N.E.2d 1273, 1277 (1977). This is as absurd as urging that the standard of proof in criminal trials should be lower because the difficulty of proving guilt beyond a reasonable doubt leaves many guilty people unpunished.

164. The judge will likely be cautious about releasing persons labeled as dangerous even under the clear and convincing standard, given the numerous "horror stories" about persons who committed suicide or killed another person upon release from the hospital. See Treffert, The Practical Limits of Patient's Rights, 15 PsYCH. ANNAls 91 (April 1975); $f f$. Tarasoff v. Regents of the Univ. of.Cal., 17 Cal. 3d 425, 551 P.2d 334, 131 Cal. Rptr. 14 (1976) (psychiatrist liable for negligent failure to warn victim of patient's threats). In particular, a judge could find clear and convincing evidence of dangerousness if the individual has acted violently during the hospitalization period, although prior acts or threats alone are not necessarily good predictors of dangerousness. See Developments-Civil Commitment, supra note 2, at 1301-02; 
The clear and convincing standard will have its most important effect on judges. At present, judges have broad discretion in deciding whether to grant petitions for release from certification. The intermediate standard will oblige them to consider the evidence more critically, thereby avoiding the presumption that the petitioner is mentally ill and that the petitioner's interests in avoiding confinement should therefore be discounted. Specifically, when applied to the elements of grave disability or dangerousness, the clear and convincing standard will help prevent commitment on the constitutionally impermissible ground of mental illness alone.

\section{Conclusion}

Courts and legislatures must look critically at the substantive standards for civil commitment, to ensure that people are not involuntarily hospitalized merely because society does not want them. Nevertheless, "[t]he history of liberty has largely been the history of procedural safeguards."165 Procedural safeguards can help to prevent erroneous commitment, and the consequent deprivation of liberty, good name, and even mental health, that commitment entails. By examining the process of short-term commitment through the example of the LPS Act's 14-day certification process, this note has argued that requiring the state to justify short-term commitment by bearing the burden of proof by clear and convincing evidence is a vital addition to procedural due process. Though the courts could theoretically enforce such a requirement by constitutional holdings, the rational path is for legislatures to assign the burden and establish the standard of proof in unmistakable statutory language.

Lynne N. Henderson

Comment, Overt Dangerous Behavior as a Constitutional Requirement for Involuntary Civil Commitment of the Mentally IIl, 44 U. CHI. L. REv. 562, 583-85 (1977).

On the other hand, caution about releasing individuals has led to equally tragic results. One commentator relates the story of a Polish immigrant who had been in a Nazi concentration camp and who was committed because he could not speak English. Unable to obtain release from the hospital because of his inability to communicate, the man committed suicide, apparently out of fear and despair. See Kutner, The Illusion of Due Process in Commitment Proceedings, 57 Nw. U.L. REV. 383, 383-84 (1962).

165. McNabb v. United States, 318 U.S. 332, 347 (1943) (Frankfurter, J.). 
. 